\title{
Associative reaction time, meaningfulness, and pronunciability ratings of 382 words and paralogs
}

\author{
RONALD LEY and EDWARD TESINY \\ State University of New York, Albany, New York 12222
}

\begin{abstract}
A list of 75 CVCVC words and paralogs were assessed for associative reaction time, meaningfulness ( $\mathrm{a}^{\prime}$, rated association frequency), and pronunciability. Uncorrected split-half reliability coefficients of correlation were, respectively, .97, .89, and .90. Intercorrelations were consistent with those of a list of 319 CVCVCs previously assessed for associative reaction time, meaningfulness ( $a^{\prime}$ ), and pronunciability. Sixty-three of the 75 CVCVCs were added to the list of 319. Intercorrelations among the assessment variables for the combined list of 382 CVCVCs were highly consistent with the intercorrelations based on the list of 319 . This larger alphabetically ordered single list of 382 CVCVC words and paralogs containing all three assessment values will facilitate selection of units for the purposes of research.
\end{abstract}

A list of 319 CVCVC words and paralogs were assessed for associative reaction time by Taylor and Kimble (1967), for meaningfulness $\left(a^{\prime}\right.$, rated association frequency, and $\mathrm{m}^{\prime}$, scaled rated association frequency) by Locascio and Ley (1972), and for pronunciability by Ley and Karker (1974). A second list of 75 CVCVC words and paralogs, 63 of which are different from those of the Taylor and Kimble list of 319 , were assessed for meaningfulness ( $\mathrm{Mn}$, associative frequency) by Andreas (Note 1). The purpose of the present study was to determine the associative reaction time, meaningfulness $\left(a^{\prime}\right)$, and pronunciability ratings for the 63 CVCVCs assessed by Andreas so that the list of 319 CVCVCs could be increased to 382 , thus extending the usefulness of the list for future research.

Since the assessments of the 319 CVCVCs were published in three separate studies, the normative list of the present study was designed to include the associative reaction time measures, meaningfulness assessments $\left(\mathrm{a}^{\prime}\right)$, and pronunciability ratings for all 382 CVCVC words and paralogs, thus facilitating the ease with which items from the list can be selected with respect to their assessment characteristics.

\section{PHASE I: ASSOCIATIVE REACTION TIME ASSESSMENT}

\section{Method}

Subjects. The subjects were 40 paid male and female undergraduate students at the State University of New York at Albany, naive with respect to prior experience in verbal learning studies.

This research was supported in part by a State University of New York Research Foundation grant-in-aid and State University of New York Research Foundation faculty research fellowship to the first author. Requests for reprints should be sent to Ronald Ley, State University of New York, 1400 Washington Avenue, Albany, New York 12222.
Materials. The verbal units consisted of Andreas' (Note 1) list of 75 CVCVCs. All CVCVCs were typed in capital letters and photographed to produce $35-\mathrm{mm}$ slides containing one unit per slide. Units were presented to subjects via a Kodak Carousel slide projector fitted with a tachistoscope. The tachistoscope was connected to a Hunter Klockounter, as was a Lafayette voice-key microphone to sense subjects' responses. The experimenter controlled the presentation of the CVCVC units via a manual switch which simultaneously started the clock counter. The clock counter was stopped by the sound of the subject's voiced verbal association to the CVCVC.

Procedure. The method for obtaining associative reaction time was essentially the same as that used by Taylor and Kimble (1967). Each subject upon entering the experimental room was assigned to one of two random orders of the 75 CVCVC units. Subjects were seated in front of a screen at approximately eye level at a distance of approximately $1.2 \mathrm{~m}$, and the voice-key microphone was placed on the table in front of them. The size of the projected CVCVC unit was approximately $27.5 \mathrm{~cm} \times 7.5 \mathrm{~cm}$. When the experimenter presented a CVCVC unit, the clock counter was automatically started. Upon the subject's giving a response (association) into the microphone, the clock counter was stopped and the experimenter recorded the elapsed time between the presentation of the verbal unit and the voiced association. This procedure was followed for each of the 75 CVCVC units.

The subjects were instructed to give their first association to each unit as quickly as possible. Following a detailed reading of the instructions by the experimenter and before the experimental list was presented, subjects were given seven practice items and were asked if there were any questions. Before each unit was presented, the experimenter gave the subject a ready signal.

\section{PHASE II: MEANINGFULNESS ( $\left.a^{\prime}\right)$ AND PRONUNCIABILITY RATINGS}

\section{Method}

Subjects. The subjects were 64 male and female undergraduates at the State University of New York at Albany, naive with respect to prior experience in verbal learning studies. Seven subjects were eliminated because their ratings consisted primarily of 1 or 2 points on the scale and totaled 
Table 1

Associative Reaction Time (RT), Rated Association Frequency (a'), and Pronunciability Ratings (PR) for 382 CVCVC Words and Paralogs

\begin{tabular}{|c|c|c|c|c|c|c|c|c|c|c|c|}
\hline CVCVC & RT & $a^{\prime}$ & PR & CVCVC & RT & $a^{\prime}$ & PR & CVCVC & RT & $a^{\prime}$ & PR \\
\hline BABEL & 2.14 & 3.20 & 2.22 & DERAY & 3.14 & 1.90 & 3.84 & HOTEL & 2.24 & 4.48 & 1.81 \\
\hline BAKER & 2.24 & 4.28 & 1.85 & DEVIL & 2.31 & 4.44 & 2.00 & HOVEL & 2.21 & 3.20 & 3.88 \\
\hline *BAKOV & 1.57 & 1.81 & 6.64 & DIGIT & 1.80 & 4.00 & 3.41 & ${ }^{*}$ HUKAN & 3.11 & 1.50 & 6.74 \\
\hline BALAP & 2.82 & 1.62 & 4.60 & DIJON & 3.27 & 2.15 & 5.92 & HUMOR & 1.95 & 4.33 & 2.64 \\
\hline BALAS & 3.04 & 1.79 & 3.67 & DINAR & 2.45 & 2.74 & 4.40 & HUMUS & 2.85 & 3.36 & 3.76 \\
\hline BARON & 2.79 & 3.48 & 2.15 & *DINER & 2.01 & 4.46 & 1.48 & HYRAX & 4.04 & 1.66 & 4.81 \\
\hline BASIS & 2.52 & 3.72 & 2.48 & DIVAN & 1.86 & 2.94 & 2.81 & HYSON & 4.04 & 1.64 & 4.22 \\
\hline BATIK & 3.25 & 1.82 & 5.48 & DIVOT & 2.48 & 2.72 & 3.63 & JABOT & 2.74 & 2.00 & 4.52 \\
\hline BATON & 2.18 & 3.54 & 3.40 & *DOBUT & 2.38 & 2.12 & 5.29 & JALEP & 2.87 & 1.51 & 5.00 \\
\hline BEDEL & 3.05 & 1.76 & 4.24 & DOLOR & 2.24 & 2.87 & 4.20 & JEHAD & 3.85 & 1.66 & 5.59 \\
\hline *BEFOG & 2.80 & 2.69 & 4.42 & DOWER & 2.49 & 2.62 & 3.04 & JERID & 3.47 & 1.56 & 4.04 \\
\hline BERYL & 2.47 & 2.38 & 4.68 & DOZEN & 1.81 & 4.26 & 2.28 & JEWEL & 2.10 & 4.51 & 3.44 \\
\hline BEZEL & 3.38 & 2.08 & 4.36 & *DUCAL & 2.54 & 2.19 & 5.26 & JIHAD & 4.18 & 1.56 & 5.41 \\
\hline BIGOT & 3.42 & 3.90 & 2.16 & DUCAT & 2.87 & 2.41 & 4.44 & JULEP & 2.12 & 2.90 & 3.89 \\
\hline *BIMOR & 2.95 & 1.88 & 6.45 & DUROC & 3.17 & 1.69 & 5.68 & JUPON & 2.83 & 1.84 & 4.81 \\
\hline BISON & 2.54 & 3.30 & 3.32 & FACET & 2.36 & 3.62 & 2.36 & JURAT & 2.80 & 1.97 & 4.36 \\
\hline BOGEY & 3.10 & 2.97 & 4.04 & FAKIR & 2.61 & 2.48 & 6.04 & JUREL & 2.39 & 1.72 & 5.20 \\
\hline BOLUS & 2.78 & 1.66 & 3.30 & FAROD & 2.91 & 1.54 & 3.89 & JUROR & 2.16 & 3.79 & 3.64 \\
\hline *BORAX & 2.09 & 3.62 & 2.42 & FAVOR & 2.81 & 3.94 & 2.11 & *JUYER & 2.90 & 1.73 & 6.87 \\
\hline BORON & 2.87 & 2.56 & · 3.19 & ${ }^{*}$ FAVOW & 1.81 & 1.73 & 7.19 & КАВОВ & 3.30 & 2.54 & 3.64 \\
\hline *BOSUM & 2.67 & 3.38 & 3.39 & FELID & 2.93 & 1.97 & 3.93 & KALAB & 3.79 & 1.76 & 3.59 \\
\hline BOSUN & 3.03 & 2.64 & 4.76 & FELON & 2.86 & 1.97 & 3.32 & KAPOX & 3.82 & 1.84 & 5.52 \\
\hline BOWER & 3.02 & 2.94 & 3.20 & FEMUR & 2.45 & 3.08 & 3.72 & KARAT & 2.16 & 3.62 & 3.84 \\
\hline *BOXER & 2.42 & 4.08 & 2.19 & FETOR & 3.60 & 1.90 & 4.40 & KARON & 3.04 & 2.00 & 3.18 \\
\hline BOYAR & 3.04 & 2.08 & 5.00 & FEVER & 2.06 & 4.26 & 2.26 & KETEL & 2.52 & 2.10 & 3.22 \\
\hline BUBAL & 3.16 & 1.74 & 4.52 & FJBER & 2.20 & 4.12 & 1.96 & KEVEL & 3.16 & 1.74 & 3.93 \\
\hline BUTYL & 3.32 & 2.02 & 5.24 & *FINAL & 1.70 & 4.19 & 1.64 & KORAN & 2.34 & 3.66 & 2.76 \\
\hline CABAL & 2.90 & 2.41 & 3.51 & FOCUS & 2.00 & 4.18 & 1.78 & KULAK & 4.10 & 2.10 & 4.41 \\
\hline${ }^{*} \mathrm{CABIN}$ & 1.84 & 4.27 & 1.58 & FORAY & 2.82 & 2.66 & 3.33 & KUPOD & 2.67 & 1.76 & 5.36 \\
\hline CADET & 2.05 & 4.02 & 2.44 & FORUM & 2.17 & 4.05 & 2.76 & *KUWIL & 3.28 & 1.73 & 7.13 \\
\hline CALIX & 3.24 & 1.87 & 4.22 & *FUMOR & 2.76 & 2.77 & 4.36 & ${ }^{*}$ LABAR & 2.24 & 2.65 & 5.73 \\
\hline *CANAL & 2.08 & 4.00 & 1.77 & FURAN & 2.68 & 1.74 & 3.85 & LAGAN & 2.80 & 1.69 & 4.68 \\
\hline CAPER & 2.45 & 3.72 & 2.12 & FUROR & 2.47 & 3.46 & 3.58 & LAGER & 2.69 & 3.54 & 3.36 \\
\hline CAPON & 2.74 & 2.82 & 3.84 & GADID & 3.39 & 1.58 & 4.70 & LAPIN & 2.52 & 2.18 & 2.63 \\
\hline CAROM & 3.10 & 1.79 & 5.84 & ${ }^{*}$ GAKED & 2.68 & 1.73 & 5.26 & LATUK & 3.55 & 1.62 & 4.96 \\
\hline CELOM & 3.28 & 1.92 & 5.26 & GALAX & 2.12 & 2.82 & 3.89 & LEMUR & 3.13 & 2.28 & 4.15 \\
\hline${ }^{*}$ CIDER & 1.47 & 4.08 & 1.77 & GAMIN & 2.70 & 2.46 & 4.88 & ${ }^{*}$ LEVER & 2.46 & 3.92 & 2.06 \\
\hline *CIFUR & 2.82 & 2.27 & 6.48 & GAMUT & 3.34 & 2.66 & 2.74 & LILAC & 1.91 & 4.10 & 2.30 \\
\hline CIVET & 2.71 & 1.97 & 4.85 & GAVEL & 2.28 & 3.44 & 2.84 & LIMEN & 2.40 & 1.69 & 4.80 \\
\hline${ }^{*}$ CIXAR & 2.26 & 1.92 & 7.26 & GEMOT & 3.38 & 1.44 & 4.36 & LIMIT & 2.20 & 4.18 & 2.15 \\
\hline COKEM & 3.08 & 1.82 & 3.52 & GENET & 3.08 & 2.76 & 4.96 & LIPID & 2.64 & 2.38 & 2.89 \\
\hline COLIC & 2.33 & 3.28 & 2.78 & GENUS & 2.31 & 3.72 & 3.20 & LITAS & 3.37 & 1.56 & 3.33 \\
\hline COMIC & 2.12 & 4.51 & 2.37 & GERAH & 3.49 & 1.84 & 5.68 & LOCUS & 2.46 & 3.74 & 2.52 \\
\hline CONIC & 2.33 & 3.02 & 3.26 & ${ }^{*}$ GIKEL & 3.23 & 1.62 & 6.71 & LOGIC & 2.43 & 4.00 & 2.56 \\
\hline COVEY & 2.13 & 2.56 & 3.44 & GOJEY & 3.35 & 1.64 & 6.76 & LOGOS & 2.53 & 2.69 & 2.63 \\
\hline CUBEB & 2.70 & 2.30 & 7.08 & GOLEM & 4.03 & 1.94 & 4.20 & LORIS & 2.80 & 1.84 & 3.52 \\
\hline CUBIT & 2.37 & 2.97 & 2.48 & GORAL & 2.62 & 1.64 & 4.24 & LOTUS & 1.94 & 3.56 & 2.33 \\
\hline CUMIN & 3.70 & 2.23 & 4.18 & *GOWIP & 1.90 & 1.50 & 6.94 & LUCES & 3.16 & 2.28 & 4.48 \\
\hline CUPEL & 2.39 & 1.79 & 5.04 & *GUPAC & 3.76 & 1.38 & 7.48 & LUMEN & 3.57 & 2.66 & 4.12 \\
\hline CYCAD & 3.21 & 1.66 & 6.60 & ${ }^{*}$ GUROY & 3.00 & 1.65 & 6.81 & MACAW & 2.42 & 2.20 & 5.28 \\
\hline CYLIX & 3.62 & 1.74 & 6.60 & GYRUS & 2.91 & 2.05 & 5.40 & MANOR & 2.01 & 4.30 & 2.32 \\
\hline CYNIC & 3.35 & 3.56 & 3.41 & HABIT & 2.71 & 3.94 & 2.16 & MANUS & 2.53 & 2.74 & 3.68 \\
\hline DAMAN & 3.42 & 2.15 & 3.64 & HAFIZ & 3.51 & 1.84 & 5.62 & MATER & 1.97 & 3.10 & 3.52 \\
\hline DATUM & 2.63 & 2.84 & 3.04 & HAKIM & 3.78 & 1.92 & 4.92 & MAVIS & 3.18 & 2.00 & 3.30 \\
\hline DAVIT & 2.94 & 1.84 & 4.16 & ${ }^{*}$ HAVEN & 2.45 & 3.69 & 1.87 & MAXIM & 2.33 & 3.51 & 3.04 \\
\hline *DAVOH & 3.18 & 1.42 & 6.32 & HAVOC & 2.35 & 3.41 & 2.22 & MEDAL & 2.43 & 4.38 & 2.32 \\
\hline *DECAY & 2.29 & 4.38 & 1.68 & HELIX & 3.10 & 2.28 & 4.04 & MENAD & 3.72 & 1.64 & 4.85 \\
\hline DECOR & 2.36 & 3.82 & 3.32 & HELOT & 3.43 & 2.02 & 3.76 & ${ }^{*}$ MENOR & 2.28 & 2.31 & 5.45 \\
\hline DECOY & 2.35 & 4.02 & 2.52 & HERES & 3.24 & 2.54 & 3.93 & MERIT & 2.21 & 3.97 & 2.20 \\
\hline *DEFER & 3.00 & 3.58 & 2.64 & HEXAD & 3.06 & 1.87 & 4.96 & MESON & 2.95 & 2.05 & 4.37 \\
\hline DEMON & 2.15 & 4.33 & 2.68 & HEXYL & 3.24 & 2.23 & 5.64 & METAL & 2.32 & 4.36 & 1.85 \\
\hline DEMUR & 2.75 & 3.20 & 3.52 & HOKUM & 3.28 & 2.33 & 4.56 & ${ }^{*}$ METAZ & 2.97 & 1.85 & 6.61 \\
\hline DEPOT & 1.98 & 3.62 & 3.11 & HONEY & 2.04 & 4.26 & 1.96 & *METEL & 2.31 & 3.73 & 4.00 \\
\hline
\end{tabular}


Table 1 Continued

\begin{tabular}{|c|c|c|c|c|c|c|c|c|c|c|c|}
\hline CVCVC & RT & $a^{\prime}$ & PR & CVCVC & RT & $a^{\prime}$ & PR & CVCVC & RT & $a^{\prime}$ & PR \\
\hline METIS & 3.50 & 1.90 & 4.84 & REMEX & 3.14 & 1.79 & 3.74 & *VARUC & 2.84 & 1.46 & 6.48 \\
\hline MIMIC & 2.44 & 3.82 & 2.76 & ${ }^{*}$ REPEN & 2.26 & 2.15 & 5.39 & VARUS & 2.43 & 2.08 & 4.22 \\
\hline MINIM & 2.17 & 2.92 & 5.12 & RESIN & 2.13 & 3.54 & 2.33 & VELAT & 3.13 & 1.62 & 6.00 \\
\hline MOGUL & 3.33 & 2.66 & 4.00 & RIGOR & 2.26 & 4.15 & 3.12 & VELUM & 3.01 & 2.48 & 4.96 \\
\hline MOHUR & 2.62 & 2.18 & 5.33 & RIVER & 1.91 & 4.56 & 2.33 & VENOM & 2.18 & 3.87 & 2.93 \\
\hline MONAD & 3.14 & 2.00 & 3.04 & ROBIN & 1.73 & 4.12 & 2.00 & VICAR & 2.82 & 3.26 & 3.32 \\
\hline MONEY & 2.48 & 4.66 & 2.00 & ROSIN & 2.51 & 3.12 & 2.85 & VIGIL & 2.38 & 3.79 & 3.37 \\
\hline MORON & 2.27 & 4.00 & 2.40 & ROTOR & 2.14 & 3.30 & 3.04 & VIGOR & 2.25 & 4.05 & 2.59 \\
\hline MOTIF & 2.44 & 3.38 & 2.89 & ROWEL & 2.79 & 2.00 & 4.19 & VINIM & 2.86 & 1.64 & 3.89 \\
\hline *MOTOR & 1.67 & 4.42 & 1.45 & *ROYEL & 1.93 & 3.54 & 3.74 & VINYL & 2.34 & 3.94 & 2.70 \\
\hline MUCIN & 3.34 & 1.56 & 5.84 & RUMOR & 2.81 & 4.23 & 2.56 & VIPER & 2.21 & 3.51 & 2.40 \\
\hline *MUCUS & 2.19 & 3.73 & 2.55 & SABER & 2.02 & 3.72 & 1.70 & VIRUS & 1.96 & 4.00 & 2.63 \\
\hline *MUDOV & 2.40 & 1.54 & 5.26 & SAHIB & 3.28 & 2.76 & 4.47 & VISOR & 2.21 & 3.18 & 3.11 \\
\hline MUJIK & 3.57 & 1.54 & 6.20 & SALAD & 2.00 & 4.36 & 2.40 & VIXEN & 2.96 & 2.92 & 3.37 \\
\hline *MUNEY & 1.96 & 3.58 & 4.32 & SALEP & 3.05 & 1.58 & 5.64 & VOMER & 2.95 & 1.54 & 3.96 \\
\hline NABOB & 3.74 & 1.97 & 3.19 & SALOL & 2.70 & 1.54 & 6.76 & VOWEL & 2.23 & 4.33 & 3.15 \\
\hline NADER & 4.26 & 2.58 & 2.40 & SATIN & 2.02 & 4.07 & 2.15 & VUMAC & 3.40 & 1.56 & 6.04 \\
\hline *NAKED & 2.33 & 4.31 & 1.39 & SEDAN & 1.94 & 3.97 & 2.52 & VUTAW & 4.27 & 1.36 & 6.72 \\
\hline NARES & 2.89 & 2.08 & 4.22 & SEPAL & 3.15 & 2.12 & 3.67 & WAGON & 1.84 & 4.44 & 2.24 \\
\hline *NASAL & 1.92 & 3.81 & 2.00 & SERIN & 3.36 & 2.00 & 4.20 & *WAGOT & 2.55 & 1.81 & 6.26 \\
\hline NEGUS & 2.96 & 1.90 & 4.59 & SIGIL & 3.62 & 1.62 & 4.41 & WAMUS & 3.01 & 1.69 & 3.04 \\
\hline NEROL & 2.77 & 1.41 & 3.93 & SILEX & 2.95 & 2.28 & 3.52 & WATER & 2.02 & 4.62 & 2.33 \\
\hline NEXUS & 3.56 & 1.79 & 5.64 & SILOS & 2.30 & 3.30 & 2.85 & *WAYOT & 3.00 & 1.92 & 6.61 \\
\hline NIDUS & 4.16 & 1.62 & 4.25 & SINEW & 2.32 & 3.02 & 5.16 & WIDOW & 2.35 & 4.28 & 2.40 \\
\hline NIHIL & 2.53 & 2.62 & 5.33 & SINUS & 2.07 & 4.02 & 2.92 & *WIKOR & 2.39 & 1.96 & 6.46 \\
\hline NISUS & 3.71 & 1.82 & 2.47 & SISAL & 2.84 & 1.97 & 5.24 & WIKOV & 3.59 & 1.36 & 7.08 \\
\hline NITON & $2.90^{\circ}$ & 1.90 & 4.26 & SITUS & 2.89 & 1.87 & 4.60 & WILER & 2.90 & 1.66 & 3.96 \\
\hline NOMAD & 2.25 & 4.02 & 2.22 & ${ }^{*}$ SIVEN & 2.09 & 2.27 & 5.55 & *WILUF & 2.84 & 1.46 & 7.13 \\
\hline NOVEL & 1.80 & 4.56 & 2.59 & SOPOR & 2.78 & 1.71 & 4.15 & WITAN & 2.89 & 1.44 & 4.52 \\
\hline NUMEN & 3.32 & 2.51 & 3.26 & *SUBAV & 2.00 & 1.65 & 6.97 & WOMEN & 2.19 & 4.62 & 2.72 \\
\hline NYLON & 2.16 & 4.20 & 2.80 & *SUGAR & 1.86 & 4.69 & 1.71 & *WUSAH & 2.46 & 1.46 & 6.52 \\
\hline PANEL & 2.10 & 4.10 & 2.08 & *SUGAX & 1.90 & 2.15 & 5.19 & WYDEN & 2.80 & 1.94 & 4.70 \\
\hline PAPER & 2.25 & 4.58 & 1.64 & SUMAC & 2.36 & 3.23 & 3.44 & XABIN & 3.87 & 1.87 & 6.11 \\
\hline PAROL & 2.57 & 2.76 & 3.22 & SURAL & 2.70 & 1.76 & 4.67 & *XAMEL & 1.87 & 2.15 & 6.94 \\
\hline PATEN & 2.49 & 2.76 & 3.26 & SYDAH & 3.28 & 1.66 & 5.59 & XENON & 3.94 & 2.18 & 6.40 \\
\hline PATER & 1.90 & 3.20 & 3.32 & SYNOD & 2.98 & 2.76 & 4.28 & XILOS & 3.05 & 1.90 & 6.70 \\
\hline PAVAN & 3.04 & 1.94 & 4.28 & SYRUP & 2.01 & 3.82 & 2.52 & XUBER & 3.23 & 1.90 & 6.89 \\
\hline PAVIS & 3.16 & 1.79 & 3.81 & TABOR & 3.20 & 2.28 & 3.40 & XYDER & 2.48 & 1.66 & 7.52 \\
\hline PECAN & 2.10 & 4.05 & 2.44 & TACET & 2.66 & 2.58 & 4.48 & XYLAN & 3.59 & 1.62 & 7.20 \\
\hline *PELUY & 3.33 & 1.23 & 7.16 & TALON & 2.66 & 2.94 & 3.00 & XYLEM & 4.01 & 2.44 & 5.89 \\
\hline *PERIH & 1.58 & 2.19 & 7.45 & TALUK & 3.74 & 1.58 & 4.04 & XYZAR & 3.54 & 1.62 & 8.11 \\
\hline PERIL & 2.01 & 4.05 & 2.76 & TALUS & 3.14 & 2.36 & 3.63 & YAMEN & 3.74 & 2.28 & 4.48 \\
\hline PEWIT & 2.83 & 1.82 & 4.85 & TAPIS & 2.48 & 2.02 & 4.15 & *YIWAN & 3.09 & 1.65 & 7.23 \\
\hline PICUL & 2.62 & 1.90 & 5.56 & TAROP & 3.99 & 1.56 & 4.00 & YODEL & 2.24 & 3.23 & 2.04 \\
\hline PIPIT & 2.76 & 1.87 & 3.68 & *TAWEN & 2.42 & 1.88 & 6.10 & YOKEL & 2.61 & 2.92 & 2.74 \\
\hline *PIVOT & 2.00 & 3.69 & 2.42 & TENET & 2.80 & 3.15 & 3.28 & YOLIF & 3.13 & 1.36 & 4.04 \\
\hline POKER & 1.90 & 4.44 & 1.81 & TENOR & 1.89 & 4.05 & 2.00 & YUKON & 2.36 & 3.62 & 2.62 \\
\hline POLEF & 3.74 & 1.84 & 3.89 & TILUS & 2.88 & 1.76 & 4.18 & YUROR & 3.04 & 1.82 & 5.76 \\
\hline POLYP & 3.06 & 2.74 & 4.04 & TITER & 2.77 & 2.62 & 3.32 & YUVAL & 3.71 & 1.62 & 5.20 \\
\hline POWER & 2.42 & 4.46 & 2.40 & TODAY & 1.89 & 4.58 & 1.89 & ZABER & 2.62 & 2.23 & 3.04 \\
\hline PUPIL & 2.06 & 4.28 & 2.30 & TOLAN & 3.52 & 1.69 & 3.15 & ZARAC & 4.24 & 1.30 & 5.07 \\
\hline *PUSIL & 2.97 & 1.88 & 6.71 & TONUS & 2.29 & 1.69 & 3.56 & ZEBEC & 4.02 & 1.64 & 4.96 \\
\hline PYXIS & 3.06 & 1.56 & 6.22 & TOPAZ & 2.00 & 3.76 & 2.56 & ZESAM & 3.66 & 1.66 & 6.04 \\
\hline RADAR & 2.55 & 4.08 & 2.24 & TOPIC & 2.38 & 3.97 & 2.00 & ZIROL & 3.65 & 1.44 & 4.74 \\
\hline RAJAH & 2.49 & 3.12 & 5.08 & TORUS & 2.99 & 2.97 & 3.40 & ZOBEL & 3.72 & 1.56 & 5.00 \\
\hline RATAL & 2.64 & 1.66 & 5.40 & TOTEM & 1.84 & 3.58 & 2.28 & ZOBIT & 3.24 & 1.69 & 4.88 \\
\hline RATAN & 3.11 & 2.54 & 5.40 & *TOTOR & 2.10 & 2.50 & 5.74 & ZOLAR & 2.81 & 2.05 & 3.40 \\
\hline *RAVEL & 2.50 & 3.15 & 2.90 & TUBER & 2.50 & 2.92 & 3.12 & ZONAD & 3.70 & 1.90 & 3.48 \\
\hline RAVEN & 1.78 & 4.00 & 2.72 & TULIP & 1.83 & 4.30 & 2.15 & ZONER & 2.60 & 2.36 & 2.74 \\
\hline RAZOR & 1.69 & 4.30 & 2.80 & TUNIC & 2.14 & 3.79 & 2.48 & ZORON & 3.52 & 1.94 & 3.96 \\
\hline REBEC & 2.87 & 2.26 & 5.04 & VAGUS & 2.83 & 2.79 & 3.52 & ZUBER & 3.00 & 1.74 & 3.48 \\
\hline REBUS & 3.70 & 2.00 & 4.00 & VALET & 2.16 & 3.44 & 2.96 & ZUMAP & 3.48 & 1.54 & 5.96 \\
\hline *REBUT & 2.48 & 3.35 & 3.64 & VALOR & 2.17 & 3.66 & 2.44 & ZUREN & 4.65 & 1.48 & 3.85 \\
\hline *RELEW & 2.49 & 1.54 & 6.87 & VAPOR & 2.09 & 3.97 & 2.59 & & & & \\
\hline RELIC & 2.07 & 3.51 & 2.30 & VARIX & 2.65 & 2.10 & 5.37 & & & & \\
\hline
\end{tabular}


Table 2

Intercorrelation Coefficients Among Associative Reaction Time (RT), Meaningfulness (a'), and Pronunciability Ratings (PR) for Three Samples of Different Size

\begin{tabular}{|c|c|c|c|c|c|c|}
\hline & \multicolumn{2}{|c|}{$\begin{array}{l}\text { Sample } \\
N=75\end{array}$} & \multicolumn{2}{|c|}{$\begin{array}{c}\text { Sample } \\
\mathrm{N}=319\end{array}$} & \multicolumn{2}{|c|}{$\begin{array}{r}\text { Sample } \\
\mathrm{N}=382 \\
\end{array}$} \\
\hline & $a^{\prime}$ & RT & $a^{\prime}$ & $\mathrm{RT}$ & $a^{\prime}$ & RT \\
\hline $\begin{array}{l}\text { RT } \\
\text { PR }\end{array}$ & $\begin{array}{l}-.56 \\
-.96\end{array}$ & . . .49 & $\begin{array}{l}-.71 \\
-.78\end{array}$ & .65 & $\begin{array}{l}-.68 \\
--.77\end{array}$ & .45 \\
\hline
\end{tabular}

$50 \%$ of all ratings. Therefore, ratings were based on 26 subjects in the meaningfulness group and 31 subjects in the pronunciability group.

Materials. The materials consisted of the entire list of 75 CVCVC verbal units previously assessed for meaningfulness (Mn, associative frequency) by Andreas (Note 1).

Procedure. In the assessment of meaningfulness $\left(\mathrm{a}^{\prime}\right.$, rated associative frequency) and pronunciability, the 75 CVCVCs were randomly placed in two word orders and typed in three columns on $8 \frac{1}{2} \times 11$ in. paper with a blank space to the right of each CVCVC unit for subjects to record their ratings. The lists contained cover sheets with instructions to subjects for obtaining either meaningfulness ratings or pronunciability ratings. An undergraduate class of 64 subjects was randomly divided, half receiving instructions for obtaining meaningfulness ratings and half receiving instructions for obtaining pronunciability ratings. Within each group, half of the subjects received one random word order and half received a different random word order.

The method for obtaining meaningfulness ratings was fashioned after that method used by Noble, Stockwell, and Pryer (1957). That is, subjects were instructed to estimate the number of associations they could make to each CVCVC unit in relation to the other units along a continuum from 1 (none) to 5 (very many). Subjects were instructed first to skip around the page to experience the range of the combinations of CVCVC units involved. Subjects were then instructed to go back to the first unit and proceed to rate all the units on the list as per instructions.

The method for obtaining pronunciability ratings was the same as that used by Ley and Karker (1974). Briefly, subjects were instructed to rate the ease of pronunciability of each CVCVC unit in relation to the other units along a continuum from 1 (easiest pronunciability) to 9 (hardest pronunciability). The subjects were instructed first to skip around the page and pronounce to themselves a sample of eight verbal units to get the idea of the range of pronunciability in the list. They were then instructed to go back to the first unit and proceed to rate all the units on the list, pronouncing each to themselves before rating.

\section{RESULTS AND DISCUSSION}

The 382 CVCVCs are listed alphabetically in Table 1 (the 63 CVCVCs previously assessed by Andreas are indicated by an asterisk), each with its corresponding mean associative reaction time, mean meaningfulness rating $\left(\mathrm{a}^{\prime}\right)$, and mean pronunciability rating.

An estimate of the reliability of the procedures for assessing the associative reaction time, meaningfulness, and pronunciability ratings for all of the CVCVCs previously assessed by Andreas $(\mathrm{N}=75)$ was determined by the split-half method. The reliability coefficient of correlation between the independent halves for associative reaction time was .94 , df $=38(r=.97$ when corrected by the Spearman-Brown formula); for meaningfulness $\left(\mathrm{a}^{\prime}\right) .89, \mathrm{df}=24(\mathrm{r}=.94$, corrected $)$; and for pronunciability ratings $.90, \mathrm{df}=29(\mathrm{r}=.95$, corrected).

An estimate of the validity of the mean values of the 75 CVCVCs was obtained by comparing the intercorrelation matrix based on these $75 \mathrm{CVCVCs}$ with an intercorrelation matrix consisting of the same assessment variables, based on the 319 CVCVCs previously assessed by Taylor and Kimble (1967), Locascio and Ley (1972), and Ley and Karker (1974). Both matrices are given in Table 2, from which it can be seen that the patterns of correlations match identically (i.e., the rank orders of the absolute sizes of the correlation coefficients are the same); the correlations between meaningfulness and pronunciability are largest in both matrices, and the correlations between associative reaction time and pronunciability are smallest in both matrices.

Additional correlations based on the total list of 382 CVCVCs were computed for the purpose of determining the effect of the addition of the new group of 63 CVCVCs. A comparison of correlations based on the total list of 382 with the old list of 319 (see Table 2) shows that the pattern of coefficients is the same and that the magnitudes of the coefficients are almost identical except for the correlations between associative reaction time and pronunciability ratings, which show a decrease from .65 for the list of 319 to .45 for the list of 382 . Since the sample sizes used in the Taylor and Kimble (1967) assessment of the 319 CVCVCs $(\mathrm{N}=100)$ and in the Ley and Karker (1974) assessment of pronunciability ratings of the 319 CVCVCs $(N=52)$ were substantially larger than that used in the present assessment of associative reaction time $(\mathrm{N}=40)$ and pronunciability $(\mathrm{N}=31)$, the correlation of .65 based on the list of 319 CVCVCs is probably the more accurate index of the relationship.

\section{REFERENCE NOTE}

1.Andreas, B. Meaningfulness (m) values and common associates for paralogs and words of CVCVC format. U.S. Army Technical Memorandum 27-72. Aberdeen Proving Ground: U.S. Army Engineering Laboratory, 1972.

\section{REFERENCES}

Ley, R., \& Karker, J. Pronunciability ratings of 319 CVCVC words and paralogs previously assessed for meaningfulness and associative reaction time. Bulletin of the Psychonomic Society, 1974, 3, 421-424.

Locascio, D., \& LEY, R. Scaled-rated meaningfulness of 319 CVCVC words and paralogs previously assessed for associative reaction time. Journal of Verbal Learning and Verbal Behavior, 1972, 11, 243-250.

Noble, C. E., Stockwell, F. E., \& Pryer, H. W. Meaningfulness $\left(\mathrm{m}^{\circ}\right)$ and association value (a) in paired-associate syllable learning. Psychological Reports, 1957, 3, 441-452.

TaYlor, J., \& Kimble, G. Association value of 320 selected words and paralogs. Journal of Verbal Learning and Verbal Behavior, 1967, 6, 744-752.

(Received for publication August 18, 1975.) 